\title{
HOW IMPORTANT IS THE BUSINESS ENVIRONMENT FOR THE PERFORMANCE OF ENTERPRISES? CASE STUDY OF SELECTED EUROPEAN COUNTRIES
}

\author{
Valaskova, K., Gajdosikova, D., Kramaric Pavic, T.
}

Katarina Valaskova / University of Zilina, Faculty of Operation and Economics of Transport and Communications, Department of Economics, Univerzitna 8215/1, 01026 Zilina, Slovakia. Email: katarina.valaskova@fpedas.uniza.sk

Dominika Gajdosikova / University of Zilina, Faculty of Operation and Economics of Transport and Communications, Department of Economics, Univerzitna 8215/1, 01026 Zilina, Slovakia. Email: dominika.gajdosikova@stud.uniza.sk

Tomislava Pavic Kramaric / University of Split, University Department of Forensic Sciences, Ruđera Boškovića 33, 21000 Split, Croatia. Email: tpkramaric@unist.hr

\begin{abstract}
The business environment, its quality, and its development are important indicators of the global competitiveness of individual economies. The situation is enhanced in the European area, where the open community brings specific opportunities to expand and grow in new markets. However, it is not that easy to find the proper place to start a business, considering the financial performance and cost-effectiveness. Thus, the paper focuses on the comparative analysis of selected European countries (Slovakia, Czech Republic, Hungary, Poland, Croatia, Latvia, Lithuania, Estonia, Germany, and France) in the context of their macroeconomic and inner-markets factors in the 8-year horizon (2013-2020). The quality of the business environment is evaluated using a multi-criteria decision-making method TOPSIS and global multi-level indices such as the Global Competitiveness Index, Corruption Perception Index, and Doing Business Index. Their mutual dependence is tested by correlation coefficients. To find the statistically significant differences among the countries, the one-way analysis of variance (ANOVA) and Scheffé's post hoc tests were used. The results reveal the subsets of countries with similar business environments, which may be beneficial in increasing the global competitiveness of enterprises.

Implications for Central European audience: The comparative analysis is focused on the selected (mostly) Central European countries. This selection enables comparing the business environments with similar features and grouping them into subsets based on their economic, political, and social peculiarities. The analysis of variance proved that the business environments in Slovakia, Hungary, and Croatia are very similar, which may simplify the way of doing business in these countries. Thus, the implications of this study are crucial for better evaluation of the factors influencing the business environment, grouping attractiveness from the perspective of national enterprises, and understanding the indicators that increase the international competitiveness of enterprises.
\end{abstract}

Keywords: business environment; corporate performance; TOPSIS; GCI; CPI; DBI JEL Classification: F23; L25; O44 


\section{Introduction}

Each country has its own internal policy, which is also known as the macro environment, in which businesses are deprived of the opportunity to influence the creation of conditions in the business environment (Moller et al., 2020). A state is a primary regulator of the economy, and all administrative and financial institutions concentrated on the market are dependent on its decisions (Mittal, 2020). The sectoral environment is another dominant environment in which enterprises can modify relationships with suppliers and customers while focusing on competitive struggles (Katrandjiev et al., 2021). However, the global environment with new modern technologies, digital access, and information and communication infrastructure contributes to the possibilities of production and development of enterprises, too (Bejtkovsky et al., 2018; Sedliacikova et al., 2020).

Small and medium-sized enterprises have a considerable impact on the national economy (Safar et al., 2018), not only in the Central European area but also worldwide. They are the primary representatives of an effective labour policy. The European Union provides various programs which can help business entities and tries to improve the environment in which they operate in all possible ways. The openness of borders, and thus the possibility of expansion into new markets as well as the harmonisation of legislative, economic, and social conditions for enterprises, is one of the crucial advantages in the European area. Thus, it can be said that this blend of social, economic, cultural, and political components builds an ecosystem that either fosters or impedes entry into doing business activities after initial business failure (Guerrero \& Espinoza-Benavides, 2020). Stam and van de Ven (2021) found that the quality of the entrepreneurial ecosystem is strongly related to the prevalence of high-growth enterprises. The open community provides business units with the opportunity to expand and grow in new markets and to identify their critical success factors (Moktadir et al., 2020). Central European countries use this opportunity and locate their business entities wherever it is advantageous and economically beneficial. However, it should be noted that the macroeconomic environment and conditions for doing business do play a significant role and have to be properly measured and evaluated (Roszko-Wójtowicz \& Grzelak, 2020).

Thus, the main aim of the paper is to compare business environments in the chosen European countries based on macroeconomic factors, evaluate the factors influencing business activities, and verify the findings using appropriate statistical methods. Individual macroeconomic parameters within the European countries should be evaluated as they create a significant view of the economic situation in the countries within the common market and allow comparison of the importance of individual countries within a single community. The purpose of the paper is to evaluate the business environment in selected European countries (Visegrad countries, Baltic States, Croatia, Germany, and France) over an 8-year horizon by analysing the basic macroeconomic parameters: gross domestic product, general government debt, direct foreign investment, inflation, unemployment, exports, and imports using the multi-criteria decision-making method. As stated by Madi et al. (2016), multi-criteria decision making is a challenging but essential process. Shih et al. (2007) appended that one of the most preferred multiple objective decision-making methods is the technique for order performance by similarity to ideal solution (TOPSIS), which is a useful technique for ranking and selection of a number of externally defined alternatives and a critically important tool in the current turbulent business environment 
(Kumar et al., 2020). So, the TOPSIS method was applied to analyse the business environment in the selected European countries in order to prioritise the attributes necessary for the successful development of potential business activities, which were then confirmed by comparing the findings with three well-known indices assessing the business environment worldwide: the Corruption Perception Index, the Doing Business Index, and the Global Competitiveness Index. The study has valuable outputs as it groups the countries based on their similarities in business environments, which is very useful for the improvement of the European market competitiveness and smooth orientation in foreign markets.

The paper is divided into several sections. The literature review focuses on the summary of the most relevant and up-to-date studies, which confirm the impact of the business environment on the development of national competitiveness and also the opposite relationship. The Material and Methods section specifies the analysed countries and factors and explains the methodological steps. The Results and Discussion section presents the research findings, which are discussed in the context of other relevant studies published worldwide.

\section{Literature Review}

The business environment is the main element of the operation of individual businesses in the market and is generally determined as a set of influences that result in the existence and development of business units and sustainable growth of national economies (Kozubikova et al., 2017). Farrukh et al. (2020), in their bibliometric analysis, provided a holistic view on the development of business strategy and the environment in the recent decades and proved an increased interest of academicians and researchers in this field, declaring the importance of knowledge in the business environment research (Acs et al., 2013; Audretsch \& Belitski, 2020). Fabus (2017) stated that the results of business activities are in mutual interaction with the business environment. Thus, the quality of the business environment and complexity of corporate decision-making processes (Calabrese et al., 2018; Stefko et al., 2020, 2019) are very important. Moreover, Acs et al. (2014) highlighted the fundamental role of national systems of entrepreneurship, which are driven by individual-level opportunities and regulated by country-specific institutional features. Lafuente et al. (2016) broadened this finding, stating that national systems of entrepreneurship need to be perceived as a critical priority that enables entrepreneurs an effective allocation of their resources in national economies. The cross-country differences in economic growth, investigated by mutual dependence between institutions and entrepreneurship in an ecosystem, were analysed for 46 countries over the period 20022011 (Acs et al., 2018). Authors declared the importance of the entrepreneurial ecosystem in the economic growth of countries. In addition, the best predictor of an economic growth expectation is the firm's initial size (Terjesen \& Szerb, 2008). Bosma et al. (2018) observed that there are several important predictors of productive entrepreneurship, i.e. institutional quality, financial stability, small government and star-up skills. Acs and Szerb $(2007,2009)$ and Szerb et al. (2007) noted that to support growth of high-performance ventures, labour market reform and financial market deregulation are needed. Based on their previous findings, authors constructed a Global Entrepreneurship Index describing the specific features of entrepreneurship across countries, underlying the relationship between entrepreneurship and economic development (Szerb et al., 2013). 
Cepel et al. (2018) evaluated the quality of the business environment in Slovak and Czech areas based on a sample of 641 small and medium-sized enterprises (SMEs), focusing on several significant factors (e.g. economic and political systems; juridical, social, and technological factors or competitive environment). Their research revealed significant differences between the countries almost in each analysed factor. A robust analysis of 40,000 European enterprises in the period 2006-2014 revealed how country-specific characteristics might shape the development and profitability of SMEs and, thus, the national business environment (Gaganis et al., 2019). The authors declared the impact of national culture on the profitability of business entities, which is significantly dependent on political stability and overall institutional quality. Similar findings discussing the dependency analysis of profit measures in business entities were presented by Svabova et al. (2020). Moreover, political determinants, as well as technological, economic, and social affairs, play a significant role when entering new markets for business purposes (Kozubikova et al., 2019). The application of machine learning technologies to automation (cognitive automation), artificial intelligence, the internet of things or smart factories are only few latest technological drivers that strongly influence and support the development of the business environment (see Kovacova \& Lewis, 2021; Suler et al., 2021; Hawkins, 2021; Cunningham, 2021).

Virglerova et al. (2020) confirmed the importance of the business environment quality by the definition of key determinants and quantification of correlations among the individual determinants forming SMEs in Czech conditions. It should be noted that persisting economic changes and deregulation have also considerably affected the development of the business environment in the European area (Eling \& Schaper, 2017). Leung et al. (2019) and Kim (2021) highlighted the role of digitalisation, e-commerce, and social media in the process of successful decision making in modern global business conditions. The benefits of eco-innovations were presented by Zauskova and Reznickova (2020), Williams et al. (2020), and Lewandowska (2020). Gogokhia and Berulava (2021) explored the role of reforms in the business environment in embellishing innovation, research and development, and productivity performance of enterprises in transition economies. Calculating the differences between the mean scores for innovator and non-innovator enterprises, the authors proved that the lower the difference, the better the business conditions in terms of innovation investment stimuli. Their research showed significant mutual dependence between the analysed factors and business environment reforms. Additionally, the findings of Nam and Tram (2021) indicated that policies focused on the improvement of the business environment strengthen innovation policies and, thus, support innovation processes in SMEs. Climate change mitigation, green innovation behaviour, and sustainable finance all strongly support sustainable business development (lonescu, 2021; Kovacova \& Lăzăroiu, 2021).

Nonetheless, the individual sectors are also essential, as is proved in the study of Khan et al. (2019). Authors analysed two groups of enterprises - service and non-service - in conditions of Slovak and Czech enterprises, and they affirmed that enterprises operating in the service sector scored better in consumption and competition factors but not so good in the financial sector (compared to their counterparts in the nonservice sector). Technological factors affecting the quality of the business environment were analysed by Kozubikova and Kotaskova (2019). They declared, applying the linear regression model, that the quality of the business environment is positively influenced by the cooperation between the private 
and public sectors and the availability of human capital. Peracek et al. (2017) noted that the development of the national economy and conditions for enterprises are negatively influenced by changes in legislation, different bureaucratic burdens, or high levels of taxation. The biggest negative impacts on the quality of the business environment of small and medium-sized enterprises were the factors related to the public sector (Belas et al., 2019; Sedliacikova et al., 2012). Dragan et al. (2017) and Dankiewicz et al. (2020) portrayed potential risks in various industries and key organisational factors creating the appropriate business conditions of individual industries. Korcsmaros and Simova (2018) named the factors which influence the future development of enterprises, i.e. factors focused on inputs, outputs, sales and instruments of regional policy. Regional differences within countries also contribute to the prosperity of the national business environment, considering the level of living standards, employment, or economic life (Koisova et al., 2017; Sedliacikova et al., 2021).

Slightly different factors affecting the development of the business environment are presented by Popescu and Popescu (2019). They found a positive relationship between corporate social responsibility (CSR), and intellectual and human capital in the business environment of Romanian enterprises, which significantly improved corporate performance and productivity. Crisan-Mitra et al. (2020) investigated corporate social performance (CRP) in emerging markets, and they proved not only the importance of the CRP assessment but its impact on the environmental specificities of the markets. The mutual effect of CSR and the business environment is documented in the study of Krajnakova et al. (2018), who focused on the development of the business environment in the Baltic countries and Slovakia. The results of the study claim that economic conditions may affect the CSR dimensions differently and that this policy is developed even in unfavourable economic conditions due to its long-lasting effect on business operations. Newman et al. (2020) similarly described a positive relationship between socially responsible actions and firmlevel efficiency and productivity that strongly developed in non-competitive industries. Dropulić and Cular (2019) confirm the indisputable link between business and society in terms of Croatian insurance companies achieving improved financial results when implementing CSR, but society and the environment as a whole benefit from socially responsible firms as well.

Contractor et al. (2020) noted the importance of foreign direct investment (FDI) inflows. On a sample of 189 economies, the crucial regulatory factors affecting the level of FDI were identified. The study observed that more FDI is attracted by those countries where there is strong contract enforcement and efficient international trade. Similar results are affirmed by Fabus (2017), who found that only countries with an attractive business environment have a higher potential for foreign investment inflow. From the FDI perspective, Peña-Vinces et al. (2017) also emphasise the role of the business environment, including changes in the political regime.

Moreover, the application of different aggregate indicators (e.g. indicators of doing business, transport efficiency, institutional quality, etc.) in the study by Borojo and Jiang (2020) disclosed that institutional quality and business environment factors are relevant motivators of FDI flows between countries. Thus, the conditions of European Union countries have a positive impact on overall economic growth and the development of business environments (Glodowska, 2017). Despite the findings that are contrary to the 
authors' expectations, Jurčić et al. (2020) also hypothesise that institutional factors encompassing political stability, regulatory quality, government effectiveness, as well as control of corruption and the rule of law attract FDI in the Croatian context. The relationship between economic growth, the business environment, and urbanisation is also verified by Ncube et al. (2021). They observed an association between strong economic growth and improvements in conditions for starting a business, although urbanisation showed a weaker correlation with business environment factors.

Current business conditions in a global context are significantly influenced not only by constantly changing trends or internationalisation but also by negative aspects, such as the last pandemic caused by the coronavirus (e.g. Donthu \& Gustafsson, 2020; Erceg et al., 2021; Grencikova et al., 2021; Maciel \& de Gamboa, 2020; Tecau et al., 2020; Vasenka et al., 2021 etc.). Belas et al. (2020), in their research, confirmed that the identification of problematic aspects of doing business in each national economy helps create appropriate mechanisms for effective structural policies or for the improvement of performance measurement systems and practices (Coatney \& Poliak, 2020; Nudurupati et al., 2021). The contemporary business environment in current conditions is enriched by knowledge creation, managerial competencies, and global challenges (Nikitina \& Lapina, 2019).

\section{Methods and Data}

The comparative analysis of the business environment includes ten European countries: Visegrad Group countries (Slovakia, the Czech Republic, Poland, and Hungary), the Baltic States (Latvia, Lithuania, and Estonia), Croatia, Germany, and France. The majority of the countries are classified as Central European not only by their geographical location but also by cultural criteria (Jordan, 2005). However, these states were included in the analysis as formerly part of the Soviet Union, which indicates their comparable development, changes in political, cultural, and economic life, and their transition to a market economy (Wrobleski, 2016). The Visegrad countries and Croatia, as Soviet-influenced Eastern Bloc countries, experienced similar transformations in their economic systems, and the development of their national economies is based on similar roots. The Baltic countries form a community of states with a similar economic environment. Their cooperative behaviour is comparable with that of the Visegrad group. However, these countries are economically developed and are classified as high-income economies. Germany and France, significant trading partners of Central European countries and states with a pro-business environment, were also included, as they may offer new opportunities and ideas for improving the situation in other countries based on their performance in their economies and business attractiveness.

To measure the development of the business environment in individual countries, key macroeconomic factors were selected as input variables: gross domestic product (GDP), general government debt (GGD), foreign direct investment (FDI), inflation (I), unemployment $(U)$, export (EX) and import (IM) and quantified in the period 2013-2020. Table 1 presents the 8-year average values in each country. 
Table 1 | 8-year average values of analysed indicators

\begin{tabular}{cccccc}
\hline Indicator & Slovakia & Czech Rep. & Poland & Hungary & Croatia \\
\hline GDP (mil. EUR) & $83,879.5$ & $188,688.4$ & $459,934.1$ & $122,716.8$ & $47,920.8$ \\
GGD (mil. EUR) & $44,309.0$ & $1,569,337.0$ & $889,950.4$ & $23,948,603.9$ & $38,484.6$ \\
FDI (mil. EUR) & $1,230.6$ & $122,968.5$ & $17,907.9$ & $6,480,044.2$ & $1,019,5$ \\
I (\%) & 1.2 & 1.6 & 1.1 & 1.8 & 0.5 \\
U (\%) & 9.5 & 4.0 & 6.0 & 5.7 & 12.2 \\
EX (\%) & 92.5 & 77.8 & 51.9 & 84.9 & 46.6 \\
IM (\%) & 89.8 & 70.9 & 48.5 & 79.0 & 47.6 \\
\hline Indicator & Estonia & Latvia & Lithuania & Germany & France \\
\hline GDP (mil. EUR) & $23,375.2$ & $53,137.9$ & $41,668.9$ & $3,166,572.5$ & $2,260,751.5$ \\
GGD (mil. EUR) & $2,492.8$ & $10,461.2$ & $16,519.0$ & $2,170,438.9$ & $2,238,876.4$ \\
FDI (mil. EUR) & 450.6 & 211.5 & 525.9 & $109,714.9$ & $52,860.9$ \\
I (\%) & 1.7 & 1.1 & 1.4 & 1.1 & 0.9 \\
U (\%) & 6.4 & 9.1 & 8.5 & 4.1 & 9.5 \\
EX (\%) & 76.4 & 60.6 & 73.5 & 46.1 & 30.3 \\
IM (\%) & 73.4 & 61.8 & 70.7 & 39.6 & 31.4 \\
\hline
\end{tabular}

Source: own processing according to https://ec.europa.eu/eurosta

In the analysed period, each country experienced positive and negative challenges that influenced their overall economic and political situation. Thus, the diversified maturity of these economies within the Central European community is indisputable. The presented input factors were used as factors of evaluation in the multi-criteria decision analysis (TOPSIS method).

The principle of the TOPSIS method is based on a selection of the variant, which is as close as possible to the ideal solution (pro-business environment) and as far as possible from the least suitable solution at the same time. The least suitable solution is the composition of the worst possible criteria among all evaluated variants. The criteria can have a maximisation or minimisation aspect, and minimisation criteria should be converted to maximisation (in our case GGD, I, $U$ and IM). The final description is based on maximisation criteria. The TOPSIS method was performed in the following steps:

1. The Saaty's matrix was used to evaluate the criteria (macroeconomic factors) in terms of their relative importance and to set their weights (Table 2). To verify the determined weights, the consistency ratio $(0.00784)$ was calculated. As long as the value of the consistency ratio is less than 0.1 , the level of inconsistency is acceptable. 
Table 2 | Weights of individual criteria

\begin{tabular}{cccccccc}
\hline Indicator & GDP & GGD & FDI & I & U & EX & IM \\
\hline$w_{i}$ & 0.335 & 0.234 & 0.134 & 0.102 & 0.085 & 0.064 & 0.045 \\
\hline
\end{tabular}

Source: own calculation

2. An evaluation matrix consisting of all countries and macroeconomic criteria was created, with an intersection of each alternative and the criteria given as $x_{i j}$. The calculated weights were then used in the TOPSIS method in each analysed year. Changing all criteria to the maximisation ones, normalised $R=r_{i j}$ and weighted normalised $W=w_{i j}$ decision matrices were calculated, creating a basis for the estimation of the ideal $H=\left(H_{1}, H_{2}, \ldots, H_{k}\right)$ and basal $D=\left(D_{1}, D_{2}, \ldots, D_{k}\right)$ alternatives, where:

$$
\begin{aligned}
& H_{j}=\max _{i} w_{i j} \quad j=1,2,3, \ldots, k \\
& D_{j}=\min _{i} w_{i j} \quad j=1,2,3, \ldots, k
\end{aligned}
$$

Subsequently, the distances of the variants from the ideal and basal alternatives were calculated (Eq. 2):

$$
\begin{aligned}
d_{i}^{+} & =\left(\sum_{j=1}^{k}\left(w_{i j}-H_{j}\right)^{2}\right)^{1 / 2} \quad i=1,2,3, \ldots, p \\
d_{i}^{-} & =\left(\sum_{j=1}^{k}\left(w_{i j}-D_{j}\right)^{2}\right)^{1 / 2} \quad i=1,2,3, \ldots, p
\end{aligned}
$$

In the last step, a parameter $c_{i}$ is determined, representing the relative distance of the variants from the basal alternative (Eq.3):

$$
c_{i}=\frac{d_{i}^{-}}{d_{i}^{-}+d_{i}^{+}} ; i=1,2, \ldots, p
$$

The $c_{i}$ values are from the interval $[0,1]$. The higher the values, the closer the variant to the ideal solution.

3. The results of the TOPSIS method enable comparing the conditions among the countries in each analysed period. Thus, the best environment for doing business can be identified. To confirm the results, the global multi-criteria indices were also assessed - Corruption Perception Index (CPI), Doing Business Index (DBI) and Global Competitiveness Index $(\mathrm{GCl})$ - and the correlation between these indices and $c_{i}$ was tested at a $5 \%$ significance level (see also Androniceanu et al., 2020).

4. The one-way analysis of variance (ANOVA) was applied to verify the statistically significant differences in the quality of the business environment among the countries:

HO: There is no statistically significant difference in the means of scores of indices assessing the business environment among the countries. 
H1: The means of scores of indices assessing the business environment are not all equal; there are statistically significant differences among the countries.

However, declaring the differences in the level of the multi-criteria indices across the countries, Scheffé's multiple comparison t-test was computed to find the statistically significant differences among the countries and identify the homogeneous subsets of countries, grouping the economies with similar business environments within the subsets and those with different business conditions between the subsets.

\section{Results and Discussion}

The selected macroeconomic factors were used as input criteria in the TOPSIS method, and the relative distance of the individual variants from the basal alternative $\left(c_{i}\right)$ was calculated for each year. A summary of the calculated values is presented in Table 3.

Table $3 \mid$ Values of $c_{i}$ in each analysed period and country

\begin{tabular}{ccccccccc}
\hline Country / year & $\mathbf{2 0 1 3}$ & $\mathbf{2 0 1 4}$ & $\mathbf{2 0 1 5}$ & $\mathbf{2 0 1 6}$ & $\mathbf{2 0 1 7}$ & $\mathbf{2 0 1 8}$ & $\mathbf{2 0 1 9}$ & $\mathbf{2 0 2 0}$ \\
\hline Slovak Republic & 0.376 & 0.215 & 0.373 & 0.222 & 0.380 & 0.373 & 0.220 & 0.247 \\
Czech Republic & 0.416 & 0.263 & 0.397 & 0.259 & 0.397 & 0.394 & 0.241 & 0.299 \\
Hungary & 0.116 & 0.333 & 0.132 & 0.349 & 0.132 & 0.120 & 0.334 & 0.404 \\
Poland & 0.414 & 0.259 & 0.408 & 0.260 & 0.418 & 0.427 & 0.271 & 0.322 \\
Croatia & 0.368 & 0.209 & 0.367 & 0.211 & 0.377 & 0.377 & 0.251 & 0.217 \\
Estonia & 0.369 & 0.268 & 0.378 & 0.254 & 0.367 & 0.365 & 0.228 & 0.216 \\
Latvia & 0.383 & 0.300 & 0.376 & 0.230 & 0.371 & 0.367 & 0.216 & 0.217 \\
Lithuania & 0.376 & 0.234 & 0.369 & 0.249 & 0.367 & 0.370 & 0.223 & 0.229 \\
Germany & 0.902 & 0.693 & 0.953 & 0.679 & 0.941 & 0.927 & 0.680 & 0.623 \\
France & 0.770 & 0.594 & 0.755 & 0.570 & 0.736 & 0.717 & 0.561 & 0.488 \\
\hline
\end{tabular}

Source: own calculation

In all monitored periods, the economies of Germany and France both reached their best values. In 2019, Hungary moved to a better position from the worst possible one compared to previous years. This ranking is followed by Poland and the Czech Republic, which both had similar developments. The Baltic countries are at the bottom of the table, in the order of Estonia, Lithuania, and the last place was occupied by Latvia. Slovakia and Croatia, very similarly, are ranked below the average values and in the second half of the rankings. The pandemic situation in 2020 did not influence the score significantly. However, a slight decrease may be observed in the top-ranked countries (Germany, France) and also in Croatia (Figure 1).

The result of the activities of individual countries is a consequence of the development of macroeconomic indicators within economies. Macroeconomic indicators developed differently in each country during the analysed period. Based on the analysis using the multi-criteria TOPSIS method, the position of selected countries from the European Union 
was recorded. Germany seems to be the country with the best business environment measured by the TOPSIS method, which can be caused by constant reduction of regulatory burdens, promotion of innovations to increase the competitiveness of the European Union countries.

Figure 1 | Development of $c_{i}$ values in analysed European countries

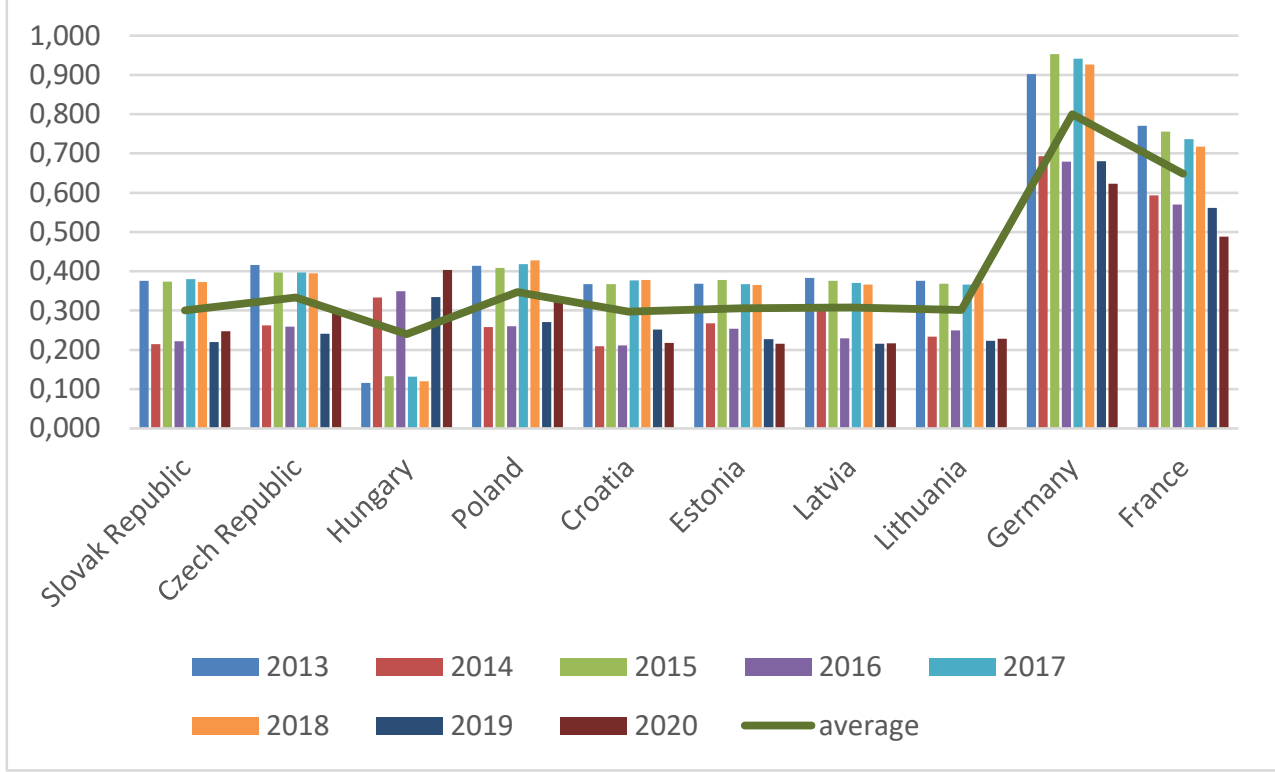

Source: own calculation

Moreover, this national market is typical for its high productivity levels, skilled labour force, quality engineering, transport infrastructure, and location in the centre of Europe (Steinhauser, 2019). France, the second country with the most pro-business environment, is an advanced and industrialised country with a sophisticated financial market, the largest capital market, great infrastructure, developed telecommunication and technology sectors, and a highly educated workforce, which makes it an attractive country for doing business (Cera et al., 2020).

However, the evaluation of the quality of the business environment of individual countries is carried out not only based on macroeconomic factors (as provided in this research using the TOPSIS method) but also through indices that approximate the internal situation in countries and their economies. Thus, the findings of our analysis are further discussed and analysed in the context of microeconomic, financial, and non-financial factors in the countries that also have a great impact on the creation of a business-supporting environment. For small and medium-sized enterprises, these characteristics are the key ones not only to start a business but also to do it successfully. So, in the given period, the multi-criteria global indices - $\mathrm{CPI}, \mathrm{GCI}$, and $\mathrm{DBI}$ - were also examined, as they play an important role in the process of sustainable competitive economic development (Kiselakova et al., 2019a; Kiselakova et al., 2020). 


\section{CPI index}

The significance of the CPI index lies in the corruption monitoring caused by an abuse of entrusted power for private profit. Countries are ranked on a scale from 0 (highly corrupt) to 100; those countries with a CPI index level in a range from 50 to 100 are perceived as less corrupt, while those in a range from 0 to 49 are more corrupt. It is evident that this factor influences the investment decisions of business units. The situation in the analysed countries is portrayed in Figure 2.

Although there has been a slight increase in Slovakia since 2013, the turn in 2017 brought a decline. In 2020, the monitored index fell again, indicting the corruption behaviour in the market. Slovakia, thus, records a medium level of corruption. In the Czech Republic, the cleanest environment was in 2018 (59 points), and since then, the index has been decreasing towards the corruption environment. The index in Poland grew slightly until 2015, but there has been a decline since then. The same development has occurred in Hungary. In Croatia, the values of the indicator reached a peak in 2015, and subsequently, a decrease in individual values was recorded. Nonetheless, the overall assessment clarifies that the business environment is more corrupt. Within the Baltic countries, a positive increase is apparent during the 8-year period, declaring the diminishing of corruption problems, with Estonia standing out in particular. Germany and France show almost stable development of the CPI index with a slight fluctuation, but their high long-term economic growth indicates the anticorruption environment (Shao et al., 2007).

\section{Figure 2 | Development of CPI index in analysed European countries}

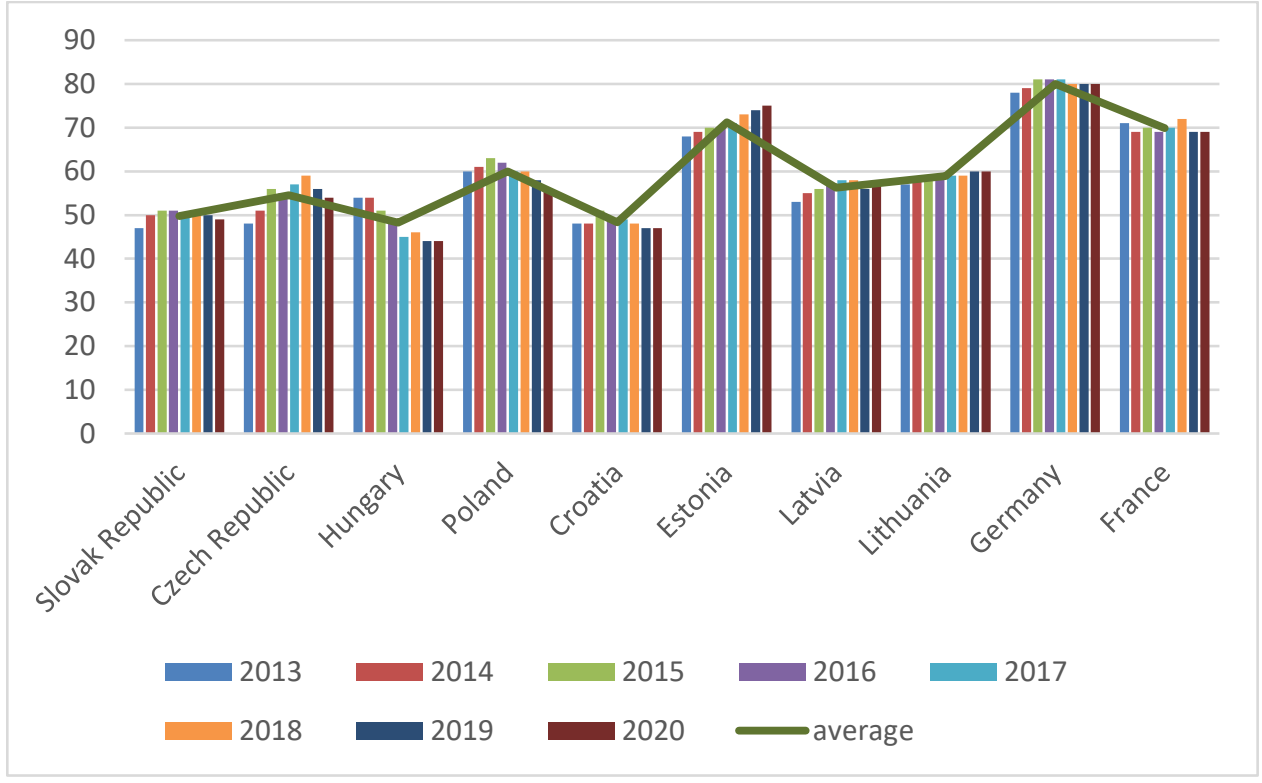

Source: own processing according to the data available at https://www.transparency.org/en/cpi

Compared to the analysis of macroeconomic indicators based on the TOPSIS method in individual years, the CPI index is less variable. In the analysed period, Slovakia had a 
different position in the analysis, so the corruption index for these years was always in a weak position, which indicates a higher level of corruption. During the analysed period, the Czech Republic was ranked in average positions within multi-criteria decision analysis, and when considering the CPI index, the country's ranking was not so optimal, achieving an average value of 54.5 points. With the use of the TOPSIS method, Poland was in the optimal position, being on average in the 4th position. The CPI index values were in the 6th position during the whole period, indicating that Poland is a territory with a medium level of corruption. The last country in the V4 group is Hungary, whose CPI index value is the worst. Compared to the TOPSIS method, Hungary was in a good position with the 3rd position in 2014, 2016, 2019, and 2020, but it was dedicated to the worst places in the remaining years. After the evaluation, the result of high corruption in the territory of the V4 countries and the instability caused by changes in macroeconomic indicators are obvious. In the monitored years, Croatia, the last country of the former Eastern Bloc countries, had a weak position within the TOPSIS method. The CPI index was ranked in the 9th position on average, which represents a relatively high level of corruption. The comparative analysis in the Baltic countries proved that Estonia, with variable positions within the TOPSIS method, was the third-best country in terms of corruption perception. Latvia had a middle position in the multi-criteria evaluation, and the CPI index was similar because it reached the 4th position. Lithuania was mainly in lower positions within the TOPSIS method, having the 5th position in the CPI index, which represents a medium level of corruption in the analysed country. Germany can be included in the best-ranked countries according to the TOPSIS method, and the CPI index also represents the highest number of points. Thus, the level of corruption reached the lowest level in the evaluated sample of European countries. France had a very favourable position within the TOPSIS method because it was ranked in the 2nd position every year, and it was also one of the least corrupt countries measured by the CPI index. The comparison of the business environment development measured by the TOPSIS method and the CPI index proved some similarities, so to declare their mutual dependence, the correlation coefficient was calculated, Table 4.

Table 4 | Correlation TOPSIS - CPI

\begin{tabular}{lll}
\hline TOPSIS - CPI & Pearson Correlation & 0.698 \\
\hline & Sig. (2-tailed) & 0.000 \\
\hline
\end{tabular}

Source: own calculation

The p-value (Sig.) of the Pearson correlation coefficient confirms that there is a high positive significant correlation between these two factors: the macroeconomic development in a country influences the level of corruption perception. Using regression analysis, Domareski-Ruiz et al. (2020) affirmed the role of the CPI index and proved the impact of the corruption perception index on the competitiveness of economies. Buterin et al. (2017) also found the CPI index to positively affect GDP per capita in post-transition countries.

\section{$D B$ Index}

The Doing Business Index is focused on the evaluation of the overall business environment in twelve different areas (procedures of starting a business, dealing with construction 
permits, protecting investors, paying taxes, getting credit, electricity connection, property registering, trading across borders, contract enforcement, insolvency resolution, labour policy regulations, and contracting with the government). It measures the distance of each economy to the frontier, which is the highest performance of the indicator across all economies (Malpass, 2020). Based on this index, the ease of doing business in each country can be classified. The higher the country's score, the better the business environment and the more conductive the regulatory environment (Figure 3).

The figure shows a relatively similar development of the $\mathrm{DBI}$ index, with a slight increase during the mapped period, which means that the regulations that encourage efficiency and support freedom of business are almost similar in all the analysed countries. Considering the economic conditions based on the level of the DBI index in the pandemic year 2020, the situation in all countries remained the same as in the previous year or slightly improved (e.g. Lithuania, Germany). In all analysed European countries, the environment for doing business was classified as very easy in 2020 (but also in other years). So the coronavirus did not affect the business environment significantly. As in the previous case, the mutual dependence of these two indicators of the quality of business environment macroeconomic factors measured by TOPSIS and the DBI index - was statistically verified by the Pearson correlation coefficient (Table 5).

Figure 3 | Development of DBI index in analysed European countries

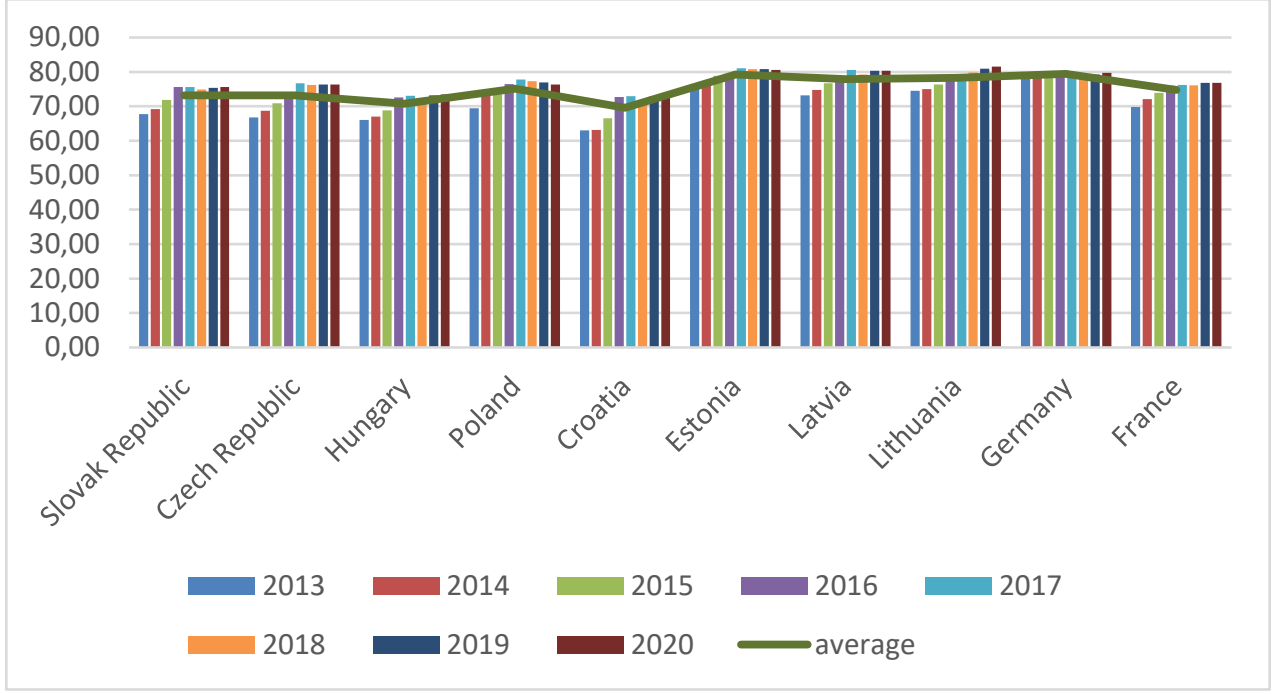

Source: own processing according to the data available at https://www.doingbusiness.org/en/data 


\begin{tabular}{lll}
\hline TOPSIS - DBI & Pearson Correlation & 0.222 \\
\hline & Sig. (2-tailed) & 0.048
\end{tabular}

Source: own calculation

The p-value (Sig.) of the Pearson correlation coefficient shows low positive significant correlation between these two factors - the macroeconomic development in a country and ease of doing business are mutually dependent (similarly to Kot \& Rajiani, 2020). Moreover, countries with a high score on the DBI index tend to have a lower level of corruption and a higher level of business activity. The DBI index as an important indicator of the business regulatory environment was analysed by Maricic et al. (2019) and Holden and Pekmezovic (2020). However, their findings revealed that the weighting scheme and conceptual grounds are not appropriate for all countries, which can result in discrepancies compared to other global multi-criteria indices.

\section{GCl index}

The Global Competitiveness Index focuses on monitoring economies by combining macroeconomic and microeconomic aspects of competitiveness into a single index, mapping economic growth, and assisting countries in identifying relevant policies and practices (Schwab et al., 2020). The higher the percentage rating, the better the country's productivity, growth and human development. The values of the $\mathrm{GCl}$ index for the analysed period are summarised in Figure 4.

Figure 4 | Development of $\mathrm{GCl}$ index in analysed European countries

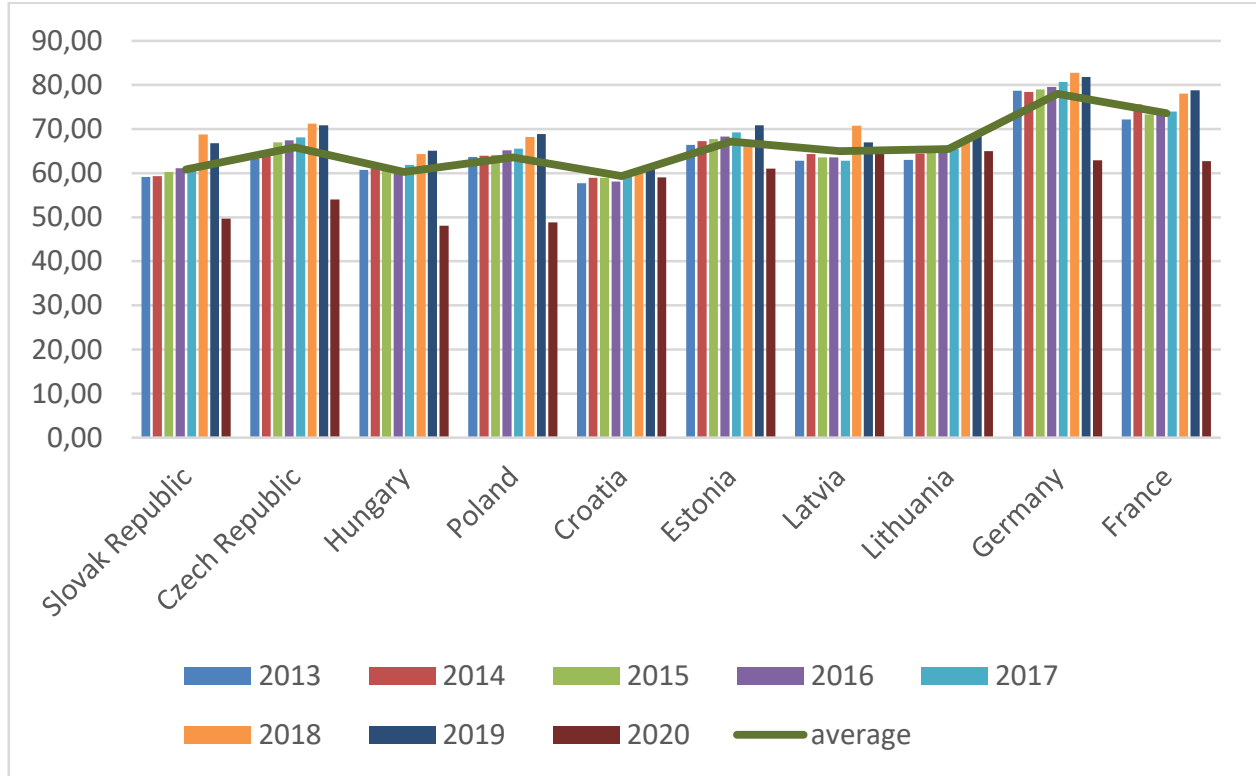

Source: own processing according to the data available at https://www.weforum.org/

In almost all the analysed countries, the $\mathrm{GCl}$ index increased in the monitored period. The first significant decrease can be noticed in 2019, and the rapid one in 2020, caused by the 
lockdown of national economies due to the COVID-19 pandemic when huge economic shocks impacted millions of households and disrupted business activities. However, not only the disconnection between national economic systems and societal resilience will be highlighted, but also some positive consequences of the pandemic may be observed in the upcoming period in the form of an accelerated industrial revolution or digitisation (Schwab et al., 2020). The mutual dependence of business environment quality measured by the TOPSIS method and the $\mathrm{GCl}$ index was verified by the calculation on the correlation coefficient, Table 6 . The outputs of the correlation analysis confirm a high positive significant correlation between these two indicators of the business environment quality.

Table 6 | Correlation TOPSIS - GCI

\begin{tabular}{lll}
\hline TOPSIS - GCI & Pearson Correlation & 0.682 \\
\hline & Sig. (2-tailed) & 0.000 \\
\hline
\end{tabular}

Source: own calculation

Thus, the overall comparison of the business environment as measured by these two indicators can be briefly summarised. The Slovak Republic had variable results using the TOPSIS method. Based on the $\mathrm{GCl}$ index, 2018 was the optimal period of the competitive environment when the macroeconomic stability of a country was ranked with the highest possible score (100). The Czech Republic had an advantageous position in the TOPSIS analysis of macroeconomic indicators, and the $\mathrm{GCl}$ index represented a quality measure of competitiveness, having the 4th best position among the monitored countries. Using the TOPSIS method, Hungary had the best ranking in 2014, 2016, 2019, and 2020, but the GCI index achieved extremely low levels, which placed the Hungarian business environment among the least attractive within the analysed countries. Although the $\mathrm{GCl}$ index of Poland was closer to a medium level of quality and was not as low as Hungary's, the country had a similar summary with a changeable development using the TOPSIS method. Croatia recorded weak values within the TOPSIS method, and very similar developments occurred during the monitoring of the $\mathrm{GCl}$ index. In the multi-criteria decision analysis of the Baltic countries, Latvia was in the best position. In the evaluation based on the $\mathrm{GCl}$ index, Latvia did not have a favourable competitive advantage because it reached an average of 6th position; similar results can be observed in Lithuania. Estonia had the best position in both 2019 and 2017. Based on the results, it is possible to evaluate the overall optimal competitive advantage based on the results, despite the middle positions, using the TOPSIS method, where it was ranked as one of the average countries. France is a country ranked at the forefront of macroeconomic indicators using the TOPSIS method, and these satisfactory values are also achieved in the $\mathrm{GCl}$ index, where individual pillars measured in this index exceed the European and North American average. A very similar situation may be observed in Germany, where the level of infrastructure, health system, and macroeconomic stability assessed within the $\mathrm{GCl}$ index are ranked the best within the Central European countries; the leadership position of this country was also confirmed in the TOPSIS method.

\section{Overall assessment}

Based on the monitoring and evaluation of the results of the TOPSIS method and of the indices of the overall business environment, it can be stated that the individual conditions in 
the economies are different. However, their mutual relations are statistically significant, and it is possible to monitor different fluctuations. These findings correspond with the outputs of Kiselakova et al. (2019b) as they declared the statistically significant dependence between the global competitiveness, corruption, and innovation potential (measured by $\mathrm{GCl}, \mathrm{Cl}, \mathrm{DBI}$, Economic Freedom Index, and Global Innovation Index) on a sample of 28 European economies. Each country has divergent economic, financial, and social conditions and, thus, provides entrepreneurs with a better concept of the market situation and better decision-making opportunities in their activities (Clark et al., 2020; Durana et al., 2021).

Table 7| ANOVA and Scheffe's post-hoc analysis of the business environment

\begin{tabular}{|c|c|c|c|c|c|c|c|c|}
\hline & \multicolumn{4}{|c|}{ TOPSIS } & \multicolumn{4}{|c|}{ CPI } \\
\hline $\begin{array}{c}\text { Between } \\
\text { groups }\end{array}$ & \multicolumn{4}{|c|}{0.000} & \multicolumn{4}{|c|}{0.000} \\
\hline \multirow{2}{*}{ Scheffe } & \multicolumn{2}{|c|}{ Subset 1} & \multicolumn{2}{|c|}{ Subset 2} & \multicolumn{2}{|c|}{ Subset 1} & \multicolumn{2}{|c|}{ Subset 2} \\
\hline & Country & Mean & Country & Mean & Country & Mean & Country & Mean \\
\hline & $\mathrm{HU}$ & 0.240 & FE & 0.649 & $\mathrm{HU}$ & 48.25 & $\mathrm{CZ}$ & 54.50 \\
\hline & $\mathrm{HR}$ & 0.297 & DE & 0.799 & $\mathrm{HR}$ & 48.38 & LV & 56.25 \\
\hline & SK & 0.300 & & & SK & 49.75 & LT & 58.88 \\
\hline & LT & 0.302 & & & & & PL & 60.00 \\
\hline & EE & 0.306 & & & \multicolumn{2}{|c|}{ Subset 3} & \multicolumn{2}{|c|}{ Subset 4} \\
\hline & LV & 0.308 & & & Country & Mean & Country & Mean \\
\hline & $\mathrm{CZ}$ & 0.333 & & & FR & 69.88 & DE & 80.0 \\
\hline & PL & 0.347 & & & EE & 71.25 & & \\
\hline & \multicolumn{4}{|c|}{ DBI } & \multicolumn{4}{|c|}{ GCl } \\
\hline $\begin{array}{l}\text { Between } \\
\text { groups } \\
\text { (Sig.) }\end{array}$ & \multicolumn{4}{|c|}{0.000} & \multicolumn{4}{|c|}{0.000} \\
\hline \multirow[t]{9}{*}{ Scheffe } & \multicolumn{2}{|c|}{ Subset 1} & \multicolumn{2}{|c|}{ Subset 2} & \multicolumn{2}{|c|}{ Subset 1} & \multicolumn{2}{|c|}{ Subset 2} \\
\hline & Country & Mean & Country & Mean & Country & Mean & Country & Mean \\
\hline & $\mathrm{HR}$ & 69.59 & $\mathrm{PL}$ & 75.17 & $\mathrm{HR}$ & 59.33 & EE & 71.13 \\
\hline & $\mathrm{HU}$ & 70.82 & LV & 77.91 & $\mathrm{HU}$ & 60.24 & FR & 73.59 \\
\hline & SK & 73.24 & LT & 78.25 & SK & 60.87 & DE & 77.98 \\
\hline & $C Z$ & 73.25 & EE & 79.25 & PL & 63.55 & & \\
\hline & FR & 74.72 & DE & 79.43 & LV & 64.99 & & \\
\hline & & & & & LT & 65.51 & & \\
\hline & & & & & $\mathrm{CZ}$ & 65.83 & & \\
\hline
\end{tabular}

Source: own calculation 
The comparison of inner-country business environments was verified using an analysis of variance (ANOVA). It provides a statistical test of whether two or more analysed countries are equal or have some statistically significant differences. The differences among the countries were represented by computing Scheffé's multiple comparison t-test, and homogenous subsets of countries were identified (Table 7). The results of Scheffe's post hoc tests summarised in Table 7 reveal that the quality of the business environment as measured by different indicators shows very similar results. Starting a business in a different country with a comparable environment can bring divergent benefits and reduce market and financial risks (Toth et al., 2020; Virglerova et al., 2020). The analysis of variance proved that the business environment in Slovakia, Hungary, and Croatia, measured by applied methods and indices, is very similar and reaches the average (in some cases, slightly below average) European values. The disadvantageous position of Visegrad countries is discussed in the research by Kiselakova et al. (2018), who highlighted public trust, government debt, and business sophistication as key sectors which need to be continuously improved to increase the global competitiveness of countries.

The GCI index and the TOPSIS method demonstrate almost the same results with two groups of enterprises; the groups of leaders (France and Germany; and also Estonia when considering the $\mathrm{GCl}$ index) and the group of other enterprises. The $\mathrm{CPI}$ index, as the only one, formed more than two subsets, but the countries in subsets 3 and $4-$ those that support economic growth, business activities, and competitiveness (Glodowska \& Pera, 2019). Slightly dissimilar outputs are presented by the DBI index (see Kiselakova et al., $2019 b$ ), where the quality of the business environment in the Baltic countries, Poland, and Germany have ranked alike, achieving the best results. The discrepancy between the subsets of countries formed by different indices may be caused by different factors used to form the applied measures (Perenyi et al., 2020) or, as stated by Maricic et al. (2019), by the incorrect weighting scheme used in some global indices (DBI index).

Summarising the results achieved, it can be argued that the business environment in Germany is the best of the analysed countries and should be an inspiration for other countries. As a part of the benefits for business units, the German economy has advantages in the registration of assets, uses a simple process of raising funds, protection and assistance for smaller investors, has developed cross-border trade and benefits associated with the taxation system. France as a developed country offers better conditions for small and medium-sized enterprises, such as easier registration, open access to the necessary capital, advantages in terms of taxes and documentation, advanced infrastructure, quality education, developed financial markets, and a high level of innovation. Germany and France are the best-ranked countries measured by TOPSIS, CPI and $\mathrm{GCl}$ indices. And as stated by Katrandjiev et al. (2021), the $\mathrm{GCl}$ index provides important data which allow evaluation of the business environment in a comparative context and, thus, enhancement of national competitiveness. It is possible to monitor the point evaluation of individual areas in the analysis of the $\mathrm{GCl}$ index where the significant position in the German market is evident. One of the evaluated pillars within the $\mathrm{GCl}$ index is the institutional framework, where ethical behaviour, corruption environment or property rights are measured. The point method of evaluation represented a scale from 1 to 7 points within the individual analysed parameters. Germany achieved up to 6 points, while France was also one of the leading countries with 5.5 points. The infrastructure is well-developed within 
these countries (6 points for both). In the macroeconomic environment, Germany occupied a leading position with a score of 6.4 points. Other evaluated parameters are the health and education of the population, where these countries also reached the dominant positions with a score of around 6.5. These countries were placed in the leading positions in the range of 5.4 to 5.7 in monitoring the other parameters as well as the quality of higher education and training. Germany is an efficient market provider of goods and services, where it received a rating of 5.3 points, while France approached with lower points. Germany is also one of the countries with a developed and well-established labour market, achieving up to 5 points in the evaluation of the working environment. Both Germany and France can be considered as technologically advanced, sophisticated and innovative countries. Marceta and Bojnec (2020) confirmed the role of $\mathrm{GCl}$ as a key indicator of the business environment, declaring that the $\mathrm{GCl}$ index is positively correlated with business sophistication and innovation and overall development.

\section{Conclusions}

During the process of the growth of small and medium-sized enterprises, it is necessary to make changes not only in the country's economy but also within the community, looking for new opportunities for business units. Companies expect the creation of conditions for proper functioning without extra financial demands, and so the recognition of markets with similar economic, political, and social backgrounds is necessary when starting a new business. The quality and development of selected European countries - most of the Central European - was analysed using the global multi-criteria indices: Global Competitiveness Index, Corruption Perception Index, and Doing Business Index and their scores were compared with the evaluation of the countries' environments by the multicriteria decision-making method, TOPSIS. This method compared the environment in the monitored countries over an 8-year horizon based on crucial macroeconomic factors (gross domestic product, general government debt, direct foreign investment, inflation, unemployment, exports and imports). The correlation analysis proved a positive and statistically significant relationship between TOPSIS and individual global indices, thus proving the correctness of the chosen parameters. The analysis of variance (ANOVA) confirmed statistically significant differences among the countries, and post hoc analysis grouped the economies with similar quality of business environments into homogeneous country subsets, which may be beneficial in the process of improving and increasing the global competitiveness of enterprises within the European area. Surprisingly, the coronavirus pandemic has not significantly influenced the quality and continuous development of the business environment.

It should be noted that despite several limitations (analysis of selected European countries, application of several global multi-level indices, limited time horizon), the results of the analysis are crucial for correct evaluation of factors that influence the quality and sustainable development of the business environment. The future motivation is to evaluate the business environment within all European Union countries and try to find the best possible opportunities for individual countries to expand in foreign markets. Moreover, it is necessary to apply more global indices (e.g. the Economic Freedom Index, the Global Innovation Index, the Human Development Index, the Global Entrepreneurship Index, etc.) or assess not only macroeconomic factors in the TOPSIS method but also some micro and meso economic features and financial performance ratios. 
This study verifies the influence of different indicators (macro and meso level factors) and global indices in assessing the quality of the business environment, which enriches the theory of the importance of business environment on business performance, especially in the context of the Central European countries. Previous studies have confirmed significant differences in the business environment's growth across the European area, but the current study groups the countries with similar entrepreneurial ecosystems. Thus, the study provides some noteworthy managerial contributions: i) the use of relevant factors and indices for proper evaluation of the different national business conditions, ii) recognition of markets with similar economic, political, and social backgrounds enabling easier operation on the foreign markets, and iii) base for improvement and increasing the competitiveness of enterprises in the European area.

\section{Acknowledgement}

This research was financially supported by the institutional research of the Faculty of Operation and Economics of Transport and Communications (University of Zilina) 1/KE/2021: The use of quantitative methods to assess corporate indebtedness.

\section{References}

Acs, Z. J., Audretsch, D. B., \& Lehmann, E. E. (2013). The knowledge spillover theory of entrepreneurship. Small Business Economics, 41(4), 757-744. https://doi.org/10.1007/s11187013-9505-9

Acs, Z. J., Autio, E., \& Szerb, L. (2014). National systems of entrepreneurship: Measurement issues and policy implications. Research Policy, 43(3), 476-494. https://doi.org/10.1016/j.respol.2013.08.016

Acs, Z. J., Estrin, S., Mickiewicz, T., \& Szerb, L. (2018). Entrepreneurship, institutional economics, and economic growth: and ecosystem perspective. Small Business Economics, 51(2), 501-514. https://doi.org/10.1007/s11187-018-0013-9

Acs, Z. J., \& Szerb, L. (2007). Entrepreneurship, economic growth and public policy. Small Business Economics, 28(2-3), 109-122. https://doi.org/10.1007/s11187-006-9012-3

Acs, Z. J., \& Szerb, L. (2009). The Global Entrepreneurship Index (GEINDEX). Foundations and Trends in Entrepreneurship, 5(5), 341-435. https://doi.org/10.1561/0300000027

Androniceanu, A.-M., Kinnunen, J., Georgescu, I., \& Androniceanu, A. (2020). A Multidimensional Approach to Competitiveness, Innovation and Well-Being in the EU Using Canonical Correlation Analysis. Journal of Competitiveness, 12(4), 521. https://doi.org/10.7441/joc.2020.04.01

Audretsch, D. B., \& Belitski, M. (2020). The role of R\&D and knowledge spillovers in innovation and

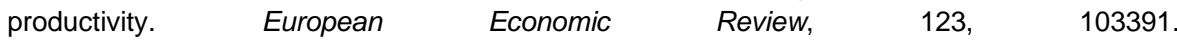
https://doi.org/10.1016/j.euroecorev.2020.103391

Bejtkovsky, J., Rozsa, Z., \& Mulyaningsih, D. H. (2018). A phenomenon of digitalisation and erecruitment in business environment. Polish Journal of Management Studies, 18(1), 58-68. https://doi.org/10.17512/pjms.2018.18.1.05

Belas, J., Strnad, Z., Gavurova, B., Bilan, Y., \& Cepel, M. (2019). Business environment quality factors research - SME management's platform. Polish Journal of Management Studies, 20(1), 64-77. https://doi.org/10.17512/pjms.2019.20.1.06 
Belas, J., Gavurova, B., Cepel, M., \& Kubak, M. (2020). Evaluation of economic potential of business environment development by comparing sector differences: Perspective of SMEs in the Czech Republic and Slovakia. Oeconomia Copernicana, 11(1), 135-159. https://doi.org/10.24136/oc.2020.006

Borojo, D. G., \& Jiang, Y. S. (2020). The impacts of institutional quality and business environment on Chinese foreign direct investment flow to African countries. Economic Research-Ekonomska Istrazivanja, 33(1), 26-45. https://doi.org/10.1080/1331766X.2019.16966

Bosma, N., Content, J., Sanders, M., \& Stam, E. (2018). Institutions, entrepreneurship, and economic growth in Europe. Small Business Economics, 52(2), 483-499. https://doi.org/10.1007/s11187018-0012-x

Buterin, V., Škare, M., \& Buterin, D. (2017). Macroeconomic model of institutional reforms' influence on economic growth of the new EU members and the Republic of Croatia. Economic researchEkonomska istraživanja, 30(1), 1572-1593. https://doi.org/10.1080/1331677X.2017.1355260

Calabrese, M., Iandolo, F., Caputo, F., \& Sarno, D. (2018) From Mechanical to Cognitive View: The Changes of Decision Making in Business Environment. In: Barile S., Pellicano M., Polese F. (eds) Social Dynamics in a Systems Perspective. New Economic Windows. Springer, Cham. https://doi.org/10.1007/978-3-319-61967-5_12

Cepel, M., Stasiukynas, A., Kotaskova, A., \& Dvorsky, J. (2018). Business environment quality index in the SME segment. Journal of Competitiveness, 10(2), 21-40. https://doi.org/10.7441/joc.2018.02.02

Cera, G., Cera, E., \& Bilan, S. (2020). Entrepreneurial intention as a function of university atmosphere, macroeconomic environment and business support: A multi-group analysis. European Journal of Training and Development. Early access. https://doi.org/10.1108/EJTD-08-2019-0148

Clark, A., Zhuravleva, N. A., Siekelova, A., \& Frajtova Michalikova, K. (2020). Industrial Artificial Intelligence, Business Process Optimization, and Big Data-driven Decision-Making Processes in Cyber-Physical System-based Smart Factories. Journal of Self-Governance and Management Economics, 8(2), 28-34. https://doi.org/10.22381/JSME8220204

Coatney, K., \& Poliak, M. (2020). Cognitive Decision-Making Algorithms, Internet of Things Smart Devices, and Sustainable Organizational Performance in Industry 4.0-based Manufacturing Systems. Journal of Self-Governance and Management Economics, 8(4), 9-18. https://doi.org/10.22381/JSME8420201

Contractor, F. J., Dangol, R., Nuruzzaman, N., \& Raghunath, S. (2020). How do country regulations and business environment impact foreign direct investment (FDI) inflows? International Business Review, 29(2), 101640. https://doi.org/10.1016/j.ibusrev.2019.101640

Crisan-Mitra, C., Stanca, L., \& Dabija, D. C. (2020). Corporate social performance: An assessment model on an emerging market. Sustainability, 12(10), 4077. https://doi.org/10.3390/su12104077

Cunningham, E. (2021). Artificial Intelligence-based Decision-Making Algorithms, Sustainable Organisational Performance, and Automated Production Systems in Big Data-Driven Smart Urban Economy. Journal of Self- Governance and Management Economics, 9(1), 31-41. https://doi.org/10.22381/jsme9120213

Dankiewicz, R., Ostrowska-Dankiewicz, A., \& Bulut, C. (2020). The attitudes of entrepreneurs of the small and medium-sized enterprises sector in Poland to key business risks. Equilibrium. Quarterly Journal of Economics and Economic Policy, 15(3), 511-536. https://doi.org/10.24136/eq.2020.023 
Domareski-Ruiz, T. C., Chim-Miki, A. F., Anana, E. S., \& dos Anjos, F. A. (2020). Impacts of megaevents on destination competitiveness and corruption perception in South American countries. Tourism \& Management Studies, 16(2), 7-17. https://doi.org/10.18089/tms.2020.160201

Donthu, N., \& Gustafsson, A. (2020). Effects of COVID-19 on business and research. Journal of Business Research, 117, 284-289. https://doi.org/10.2016/j.jbusres.2020.06.008

Dragan, K., Georges, L., \& Mustafa, K. (2017). Organisation: A new focus on mine safety improvements in a complex operational and business environment. International Journal of Mining Science and Technology, 27(4), 617-625. https://doi.org/10.1016./j.jmst.2017.05.006

Dropulić, I., \& Cular, M. (2019). The effect of corporate social disclosure practice on reporting quality: evidence from the insurance sector in Croatia. Management: Journal of Contemporary Management Issues, 24(2), 23-38. https://doi.org/10.30924/mjcmi.24.2.3

Durana, P., Michalkova, L., Privara, A., Marousek, J., \& Tumpach, M. (2021). Does life cycle affect earnings management and bankruptcy? Oeconomia Copernicana, 12(2), 425-461. https://doi.org/10.24136/oc.2021.015

Eling, M., \& Schaper, P. (2017). Under pressure: How the business environment affects productivity and efficiency of European life insurance companies. European Journal of Operational Research, 258(3), 1082-1094. https://doi.org/10.1016/j.ejor.2016.08.070

Erceg, A., Kljajic-Dervic, M., \& Gulam, V. (2021). Influence of COVID-19 on business environment example of Croatian SME Gourmet CO2. Interdisciplinary Management Research, XVII, 284306

Fabus, M. (2017). Current development of business environment in Slovakia and Czech Republic. $\begin{array}{llll}\text { Entrepreneurship and Sustainability Issues, } & \text { 5(1), }\end{array}$ https://doi.org/10.9770/jesi.2017.5.1(10)

Farrukh, M., Meng, F. C., Wiu, Y. H., \& Nawaz, K. (2020). Twenty-eight years of business strategy and the environment research: A bibliometric analysis. Business Strategy and the Environment, 29(6), 2572-2582. https://doi.org/10.1002/bse.2521

Gaganis, S., Pasiouras, F., \& Voulgari, F. (2019). Culture, business environment and SMEs' profitability: Evidence from European Countries. Economic Modelling, 78, 275-292. https://doi.org/10.1016/j.econmod.2018.09.023

Glodowska, A. (2017). Business environment and economic growth in the European Union countries: What can be explained for the convergence? Entrepreneurial Business and Economic Review, 5(4), 189-204. https://doi.org/10.15678/EBER.2017.050409

Glodowska, A., \& Pera, B. (2019). On the relationship between economic integration, business environment and real convergence: The experience of the CEE countries. Economies, 7(2), 54. https://doi.org/10.3390/economies7020054

Gogokhia, T., \& Berulava, G. (2021). Business environment reforms, innovation and firm productivity in transition economies. Eurasian Business Review, 11(2), 221-245. https://doi.org/10.1007/s40821-020-00167-5

Grencikova, A., Navickas, V., \& Huzevka, M. (2021). Slovak business environment development under the Industry 4.0 and global pandemic outbreak issues. Entrepreneurship and Sustainability Issues, 8(4), 164-179. https://doi.org/10.9770/jesi.2021.8.4(9)

Guerrero, M., \& Espinoza-Benavides, J. (2020). Does entrepreneurship ecosystem influence business re-entries after failure? International Entrepreneurship and Management Journal, 17(1), 211227. https://doi.org/10.1007/s11365-020-00694-7 
Hawkins, M. (2021). Cyber-Physical Production Networks, Internet of Things-enabled Sustainability, and Smart Factory Performance in Industry 4.0-based Manufacturing Systems. Economics, Management, and Financial Markets, 16(2), 73-83. https://doi.org/10.22381/emfm16220214

Holden, P., \& Pekmezovic, A. (2020). How accurate are the Doing Business indicators? A Pacific Island case study. Asia \& The Pacific Policy Studies, 7(3), 247-261. https://doi.org/10.1002/app5.313

Ionescu, L. (2021). Corporate Environmental Performance, Climate Change Mitigation, and Green Innovation Behavior in Sustainable Finance. Economics, Management, and Financial Markets, 16(3), 94-106. https://doi.org/10.22381/emfm16320216

Jordan, P. (2005). Großgliederung Europas nach kulturräumlichen Kriterien, Europa Regional. Leipzig: Leibniz-Institut für Länderkunde, 13 (4), 162-173.

Jurčić, L., Franc, S., \& Barišić, A. (2020). Impact of institutional quality on foreign direct investment inflow: Evidence from Croatia. Business Systems Research: International Journal of the Society for Advancing Innovation and Research in Economy, 11(1), 44-58. https://doi.org/10.2478/bsrj-2020-0004

Katrandjiev, H., Bankova, Y., \& Jovanovic, R. (2021). Do clusters and business environment foster national competitiveness in Bulgaria? A comparative study with EU countries. Casopis sa Ekonomiju I Trzisne Komunikacije, 11(1), 158-175. https://doi.org/10.7251/EMC2101158K

Khan, K. A., Cera, G., \& Netek, R. V. (2019). Perception of the selected business environment aspects by service firms. Journal of Tourism and Services, 10(19), 11-127. https://doi.org/10.29036/jots.v10i19.115

Kim, K. H. (2021). Digital and social media marketing in global business environment. Journal of Business Research, 131, 627-629. https://doi.org/10.1016/j.jbusres.2021.02.052

Kiselakova, D., Sofrankova, B., Cabinova, V., \& Onuferova, E. (2018). Competitiveness and sustainable growth analysis of the EU countries with the use of global indices methodology. Entrepreneurship and Sustainability Issues, 5(3), 581-599. https://doi.org/10.9770/jesi.2018.5.3(13)

Kiselakova, D., Sofrankova, B., Gombar, M., Cabinova, V., \& Onuferova, E. (2019a). Competitiveness and its impact on sustainability, business environment, and human development of EU (28) countries in terms of global multi-criteria indices. Sustainability, 11(12), 3365. https://doi.org/10.3390/su11123365

Kiselakova, D., Sofrankova, B., \& Cabinova, V. (2019b). The evaluation of competitive position of EU28 economies with using global multi-criteria indices. Equilibrium-Quarterly Journal of Economic and Economic Policy, 14(3), 441-462. https://doi.org/10.3390/su11123365

Kiselakova, D., Stec, M., Grzebyk, M., \& Sofrankova, B. (2020). A Multidimensional Evaluation of the Sustainable Development of European Union Countries - An Empirical Study. Journal of Competitiveness, 12(4), 56-73. https://doi.org/10.7441/joc.2020.04.04

Koisova, E., Habanik, J., Virglerova, Z., \& Rozsa, Z. (2017). SMEs financing as an important factor of business environment in Slovak Republic regions. Montenegrin Journal of Economics, 13(2), 129-140. https://doi.org/10.14254/1800-5845/2017.13-2.8

Korcsmaros, E., \& Simova, M. (2018). Factors affecting the business environment of SMEs in Nitra region in Slovakia. Oeconomia Copernicana, 9(2), 309-331. https://doi.org/10.24136/oc.2018.016

Kovacova, M., \& Lăzăroiu, G. (2021). Sustainable Organisational Performance, Cyber-Physical Production Networks, and Deep Learning-assisted Smart Process Planning in Industry 4.0- 
based Manufacturing Systems. Economics, Management, and Financial Markets, 16(3), 41-54. https://doi.org/10.22381/emfm16320212

Kovacova, M., \& Lewis, E. (2021). Smart Factory Performance, Cognitive Automation, and Industrial Big Data Analytics in Sustainable Manufacturing Internet of Things. Journal of Self-Governance and Management Economics, 9(3), 9-21. https://doi.org/10.22381/jsme9320211

Kot, S., \& Rajiani, I. (2020). Testing and identifying variable dependency through the fisher exact test in central Europe enterprises. Ekonomicko-manazerske spektrum, 14(1), 10-18. https://doi.org/10.26552/ems.2020.1.10-18

Kozubikova, L., Homolka, L., \& Kristalas, D. (2017). The effect of business environment and entrepreneurs' gender on perception of financial risk in the SMEs sector. Journal of Competitiveness, 9(1), 36-50. https://doi.org/10.7441/joc.2017.01.03

Kozubikova, L., \& Kotaskova, A. (2019). The impact of technological factors on the quality of the business environment. Transformations in Business \& Economies, 18(1), 98-108

Kozubikova, L., Kotaskova, A., Dvorsky, J., \& Kljucnikov, A. (2019). The impact of political factors' perception on sustainability of international business environment: The case of startups. Economics \& Sociology, 12(1), 61-79. https://doi.org/10.14254/2071-789X.2019/12-1/3

Krajnakova, E., Navickas, V., \& Kontautiene, R. (2018). Effect of macroeconomic business environment on the development of corporate social responsibility in Baltic countries and Slovakia. Oeconomia Copernicana, 9(3), 477-492. https://doi.org/10.24136/oc.2018.024

Kumar, R., Singh, K., \& Jain, S. K. (2020). A combined AHP and TOPSIS approach for prioritising the attributes for successful implementation of agile manufacturing. International Journal of Productivity and Performance Management, 69(7), 1395-1417. https://doi.org/10.1108/IJPPM05-2019-0221

Lafuente, E., Szerb, L., \& Acs, Z. J. (2016). Country level efficiency and national systems of entrepreneurship: A data envelopment analysis approach. Journal of Technology Transfer, 41(6), 1260-1283. https://doi.org/10.1007/s10961-015-9440-9

Leung, K. H., Luk, C. C., Choy, K. L., Lam, H. Y., \& Lee, C. K. M. (2019). A B2B flexible pricing decision support system for managing the request for quotation process under e-commerce business environment. International Journal of Production research, 57(20), 6528-6551. https://doi.org/10.1080/00207543.2019.1566674

Lewandowska, M. S. (2020). Eco-innovation and International Competitiveness of Enterprises Results for European Union Member States. Comparative Economic Research. Central and Eastern Europe, 23(1), 37-54. https://doi.org/10.18778/1508-2008.23.03

Maciel, V. F., \& de Gamboa, U. M. R. (2020). The landscape for vaccine candidates of COVID-19: Is there any relationship between innovation and the business environment of countries? Revista do Servico Publico, 71(4), 725-745. https://doi.org/10.21874/rsp.v71i4.5066

Madi, E. N., Garibaldi, J. M., \& Wagner, C. (2016). An exploration of issues and limitations in current methods of TOPSIS and fuzzy TOPSIS. In IEEE. 2016 IEEE International Conference on Fuzzy Systems (FUZZ-IEEE) (pp. 2098-2105). Vancouver, CA: IEEE. doi: 10.1109/FUZZIEEE.2016.7737950

Malpass, D. (2020). Doing Business 2020. Comparing business regulation in 190 economies. Retrieved August 20, 2021, from https://www.doingbusiness.org/en/reports/globalreports/doing-business-2020.

Marceta, M., \& Bojnec, S. (2020). Drivers of global competitiveness in the European Union countries in 2014 and 2017. Organizacija, 53(1), 37-52. https://doi.org/10.2478/orga-2020-0003 
Maricic, M., Bulajic, M., Radojicic, Z., \& Jeremic, V. (2019). Shedding light on the Doing Business Index: A machine learning approach. Business Systems Research Journal, 10(2), 73-84. https://doi.org/10.2478/bsrj-2019-019

Mittal, H. (2020). How does the institutional context of an emerging economy shape the innovation trajectory of different types of firms? A case study of India. Ekonomicko-manazerske spektrum, 14(2), 36-51. https://doi.org/10.26552/ems.2020.2.36-51

Moktadir, M. A., Kumar, A., Ali, S. M., Paul, S. K., Sultana, R., \& Rezaei, J. (2020). Critical success factors for a circular economy: Implications for business strategy and the environment. Business Strategy and the Environment, 29(8), 6311-3635. https://doi.org/10.1002/bse.2600

Moller, K., Nenonen, S., \& Storbacka, K. (2020). Networks, ecosystems, fields, market systems? Making sense of the business environment. Industrial Marketing Management, 90, 380-399. https://doi.org/10.1016/j.indmarman.2020.07.013

Nam, V. H., \& Tram, H. B. (2021). Business environment and innovation persistence: The case of small- and medium-sized enterprises in Vietnam. Economics of Innovation and New Technology, 30(3), 239-261. https://doi.org/10.1080/10438599.2019.1689597

Ncube, M., Soonawalla, K., \& Hausken, K. (2021). The links between business environment, economic growth and social equity: A study of African Countries. Journal of African Business, 22(1), 6184. https://doi.org/10.1080/15228916.2019.1695184

Newman, C., Rand, J., Tarp, F., \& Trifkovic, N. (2020). Corporate social responsibility in a competitive business environment. Journal of Development Studies, 56(8), 1455-1472. https://doi.org/10.1080/00220388.2019.1694144

Nikitina, T., \& Lapina, I. (2019). Creating and managing knowledge towards managerial competence development in contemporary business environment. Knowledge Management Research \& Practice, 17(1), 96-107. https://doi.org/10.1080/14778238.2019.1569487

Nudurupati, S. S., Garengo, P., \& Bititci, U. S. (2021). Impact of the changing business environment on performance measurement and management practices. International Journal of Production Economics, 232, 107942. https://doi.org/10.1016/j.jpe.2020.107942

Peña-Vinces, J. C., Casanova, L., Guillen, J., \& Urbano, D. (2017). International Competitiveness of Small and Medium-Sized Enterprises: Peru, a Latin American Emerging Market. Emerging Markets Finance and Trade, 53(1), 150-169, https://doi.org/10.1080/1540496X.2016.1156525

Peracek, T., Noskova, T., \& Mucha, B. (2017). Selected issues of Slovak business environment. In M. Przygoda, M. Cingula \& L. Yongqiang (Eds.), International Scientific Conference on Economic and Social Development (pp. 254-259). Warsaw, PL: Varazdin Development \& Entrepreneurship Agency.

Perenyi, A., Selvarajah, C., Tanas, J., Tuckova, Z., Odrowaz-Coates, A., Toth-Bozo, B., \& Minarova, M. (2020). Exploring ethical business in Central Europe: Leaders' values and perspectives on good practices. Sustainability, 12(2), 670. https://doi.org/10.3390/su12020670

Popescu, C. R. G., \& Popescu, G. N. (2019). An exploratory study based on a questionnaire concerning green and sustainable finance, corporate social responsibility, and performance: Evidence from the Romanian business environment. Journal of Risk and Financial Management, 12(4), 162. https://doi.org/10.3390/jrfm12040162

Roszko-Wójtowicz, E., \& Grzelak, M. M. (2020). Macroeconomic stability and the level of competitiveness in EU member states: a comparative dynamic approach. Oeconomia Copernicana, 11(4), 657-688. https://doi.org/10.24136/oc.2020.027 
Safar, L., Sopko, J., Bednar, S., \& Poklemba, R. (2018). Concept of SME business model for Industry 4.0 environment. TEM Journal-Technology Education Management Informatics, 7(3), 626-637. https://doi.org/10.18421/TEM73-20

Schwab, K., Zahidi, A., \& World Economic Forum. (2020). The Global Competitiveness Report - How countries are performing on the road to recovery. Geneva: World Economic Forum.

Sedliacikova, M., Moresova, M., Alac, P., \& Drabek, J. (2021). How do behavioural aspects affect the financial decisions of managers and the competitiveness of enterprises? Journal of Competitiveness, 13(2), 99-116. https://doi.org/10.7441/joc.2021.02.06

Sedliacikova, M., Satanova, A., \& Foltinova, A. (2012). Financial controlling in theory and praxis of small and medium-sized enterprises. Ekonomicky casopis, 60(9), 949-966.

Sedliacikova, M., Strokova, Z., Hitka, M., \& Nagyova, N. (2020). Employees versus implementing controlling to the business practice. Entrepreneurship and Sustainability Issues, 7(3), 15271540. https://doi.org/10.9770/jesi.2020.7.3(7)

Shao, J., Ivanov, P. C., Podobnik, B., \& Stanley, H. E. (2007). Quantitative relations between corruption and economic factors. The European Physical Journal B, 56 (2), 157-166

Shih, H. S., Shyur, H. J., \& Lee, E. S. (2007). An extension of TOPSIS for group decision making. $\begin{array}{llll}\text { Mathematical and Computer Modelling, 45(7-8), } & \text { 801-813. }\end{array}$ https://doi.org/10.1016/j.mcm.2006.03.023

Stam, E., \& van de Ven, E. (2021). Entrepreneurial ecosystem elements. Small Business Economics, 56(2), 809-832. https://doi.org/10.1007/s11187-019-00270-6

Stefko, R., Fedorko, R., Bacik, R., Rigelsky, M., \& Olearova, M. (2020). Effect of service quality assessment on perception of TOP hotels in terms of sentiment polarity in the Visegrad group countries. Oeconomia Copernicana, 11(4), 721-742. https://doi.org/10.24136/oc.2020.029

Stefko, R., Bacik, R., Fedorko, R., Olearova, M., \& Rigelsky, M. (2019). Analysis of consumer preferences related to the use of digital devices in the e-commerce dimension. Entrepreneurship and Sustainability Issues, 7(1), 25-33. https://doi.org/10.9770/jesi.2019.7.1(2)

Steinhauser, S. (2019). Network-based business models, the institutional environment, and the diffusion of digital innovations: case studies of telemedicine networks in Germany. Schmalenbach Business Review, 71(3), 343-383. https://doi.org/10.1007/s41464-019-00076-9

Suler, P., Palmer, L., \& Bilan, S. (2021). Internet of Things Sensing Networks, Digitized Mass Production, and Sustainable Organisational Performance in Cyber-Physical System-based Smart Factories. Journal of Self- Governance and Management Economics, 9(2), 42-51. https://doi.org/10.22381/jsme9220214

Svabova, L., Valaskova, K., Durana, P., \& Kliestik, T. (2020). Dependency analysis between various profit measures and corporate total assets for Visegrad group's business entities. Organizacija, 53(1), 80-90. https://doi.org/10.2478/orga-2020-0006

Szerb, L., Aidis, R., \& Acs, Z. J. (2013). The comparison of the Global Entrepreneurship Monitor and the Global Entrepreneurship and Development index methodologies. Foundations and Trends in Entrepreneership, 9(1), 1-142. https://doi.org/10.1561/0300000046

Szerb, L., Rappai, G., Makra, Z., \& Terjesen, S. (2007). Informal investment in transition economies: Individual characteristics and clusters. Small Business Economics, 28(2-3), 257-271. https://doi.org/10.1007/s11187-006-9019-9 
Tecau, A. S., Constantin, C. P., Lixandroiu, R. C., Chitu, I. B., \& Bratucu, G. (2020). Impact of the COVID-19 crisis on heavy work investment in Romania. Amfiteatru Economic, 22(14), 10491067. https://doi.org/10.24818/EA/2020/S14/1049

Terjesen, S., \& Szerb, L. (2008). Dice thrown from the beginning? An empirical investigation of determinants of firm level growth expectations. Estudios de Economia, 35(2), 153-178

Toth, Z., Nieroda, M. E., \& Koles, B. (2020). Becoming a more attractive supplier by managing references - The case of small and medium-sized enterprises in a digitally enhanced business environment. Industrial Marketing Management, 84, 312-327. https://doi.org/10.1016/j.indmarman.2019.07.010

Vasenka, I., Dimitrov, P., Koyundzhiyska-Davidkova, B., Krastev, V., Durana, P., \& Poulaki, I. (2021). Financial transactions using FINTECH during the COVID-19 crisis in Bulgaria. Risks, 9(3), 48. https://doi.org/10.3390/risks9030048

Virglerova, Z., Khan, M. A., Martinkute-Kauliene, R., \& Kovacs, S. (2020). The internationalisation of SMEs in Central Europe and its impact on their methods of risk management. Amfiteatru Economic, 22(55), 792-807. https://doi.org/10.24818/EA/2020/55/792

Williams, A., Suler, P., \& Vrbka, J. (2020). Business Process Optimisation, Cognitive Decision-Making Algorithms, and Artificial Intelligence Data-driven Internet of Things Systems in Sustainable Smart Manufacturing. Journal of Self-Governance and Management Economics, 8(4), 39-48. https://doi.org/10.22381/JSME8420204

Wrobleski, D. R. (2016). The complex vision on the earnings management: The evidence from Eastern European countries. Retrieved July 21, 2021 from https://zaguan.unizar.es/record/48322/files/TESIS-2016-117.pdf?version=1.

Zauskova, A., \& Reznickova, M. (2020). SoLoMo marketing as a global tool for enhancing awareness of eco-innovations in Slovak business environment. Equilibrium-Quarterly Journal of Economics and Economic Policy, 15(1), 133-150. https://doi.org/10.24136/eq.2020.007

The research article passed the review process. | Received: September 23, 2021; Revised: November 28, 2021; Accepted: November 30, 2021; Pre-published online: January 23, 2022; Scheduled release in the regular issue: September 19, 2022. 